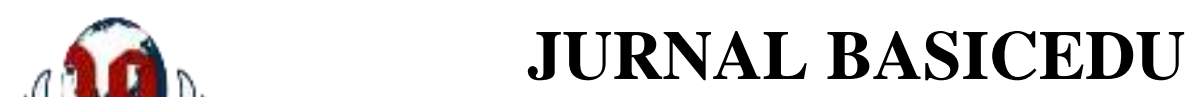

Volume 5 Nomor 5 Tahun 2021 Halaman 3999 - 4012

Research \& Learning in Elementary Education

https://jbasic.org/index.php/basicedu

$P$ AHLAWAN

\title{
Pengaruh Blended Learning terhadap Pamahaman Konsep dan Keterampilan Komunikasi dalam Pembelajaran IPA Mahasiswa PGSD di STKIP Muhammadiyah Muara Bungo
}

\author{
Sundahry $^{1 凶}$, Nurlev Avana ${ }^{2}$ \\ Program Studi Pendidikan Guru Sekolah Dasar STKIP Muhammadiyah Muara Bungo, Indonesia ${ }^{1,2}$ \\ E-mail: dahrysundahry@gmail.com ${ }^{1}$, avananurlev10@ gmail.com ${ }^{2}$
}

\begin{abstract}
Abstrak
Tujuan penelitian kuasi eksperimen ini untuk mengetahui: (1) pengaruh keterampilan komunikasi mahasiswa/i yang diberi metode blended learning dengan mahasiswa yang diberi pembelajaran konvensional; (2) pengaruh keterampilan komunikasi dengan pemahaman konsep tinggi yang menggunakan metode blended learning dibandingkan yang menggunakan pembelajaran konvensional; (3) pengaruh keterampilan komunikasi dengan pemahaman konsep rendah yang menggunakan metode blended learning dibandingkan yang menggunakan pembelajaran konvensional; (4) interaksi antara metode pembelajaran dengan pemahaman konsep terhadap keterampilan komunikasi dalam pembelajaran IPA. Subjek penelitian ini mahasiswa/I semeseter genap (6) tahun ajaran 2020/2021 kelas A dan B. Jumlah sasaran sebanyak Kelas A 30 orang dan kelas B 30 orang. Jenis penelitian ini pretest-posttest nonequivalent group design. Teknik pengumpulan data : dengan lembar tes tertulis dan lembar observasi simulasi pengajaran. Hasil penelitian menunujukan bahwa: (1) keterampilan komunikasi mahasiswa/i yang diberi metode blended learning lebih tinggi thitung $=1,910>$ ttabel $=1,708$; (2) Keterampilan komunikasi dengan pemahaman konsep tinggi menggunakan metode blended learning dan konvensional tidak ada perbedaan yang signifikan thitung $=1,87<$ ttabel $=2,56$; (3) Keterampilan komunikasi dengan pemahaman konsep rendah menggunakan metode blended learning lebih tinggi t hitung = 3,71 > t tabel = 2,56; $(4)$ tidak terdapat interaksi antar metode pembelajaran dengan pemahaman konsep terhadap keterampilan komunikasi dalam pembelajaran IPA.
\end{abstract}

Kata Kunci: IPA, blended learning, pemahaman konsep, keterampilan komunikasi.

\begin{abstract}
The purpose of this quasi-experimental research is to determine: (1) the effect of communication skills of students who are given the blended learning method with students who are given conventional learning; (2) the effect of communication skills with high concept understanding using blended learning methods compared to those using conventional learning; (3) the effect of communication skills with low concept understanding using blended learning methods compared to those using conventional learning; (4) the interaction between learning methods and understanding the concept of communication skills in science learning. . The subjects of this study were students of even semester (6) of the 2020/2021 academic year classes A and B. The number of targets was Class A 30 people and class B 30 people. This type of research is a pretest-posttest nonequivalent group design. Data collection techniques: with written test sheets and teaching simulation observation sheets. The results showed that: (1) the communication skills of students who were given the blended learning method were higher tcount $=1,910>$ ttable $=1,708$; (2) Communication skills with high concept understanding using blended learning and conventional methods have no significant difference tcount $=1.87<$ ttable $=$ 2.56; (3) Communication skill with low concept understanding using blended learning method is higher $t$ count $=3.71>t$ table = 2.56; (4) there is no interaction between learning methods and conceptual understanding of communication skills in science learning.
\end{abstract}

Keywords : IPA, science, blended learning, concept understanding, communication skills.

Copyright (c) 2021 Sundahry, Nurlev Avana

Corresponding author :

Email : dahrysundahry@gmail.com

DOI $\quad$ : https://doi.org/10.31004/basicedu.v5i5.1464

ISSN 2580-3735 (Media Cetak)

ISSN 2580-1147 (Media Online)

Jurnal Basicedu Vol 5 No 5 Tahun 2021

p-ISSN 2580-3735 e-ISSN 2580-1147 
4000 Pengaruh Blended Learning terhadap Pamahaman Konsep dan Keterampilan Komunikasi dalam Pembelajaran IPA Mahasiswa PGSD di STKIP Muhammadiyah Muara Bungo - Sundahry, Nurlev Avana

DOI: https://doi.org/10.31004/basicedu.v5i5.1464

\section{PENDAHULUAN}

Pendidikan merupakan sarana penting untuk meningkatkan kualitas sumber daya manusia dalam menjamin keberlangsungan (Dahry 2020). Jenjang pendidikan dimulai dari taman kanak-kanak (TK) hingga universitas untuk memperoleh pengetahuan. Pengetahuan artinya sesuatu yang diketahui manusia. Sementara, pengetahuan alam adalah pengetahuan tentang alam semesta dengan segala isinya. Secara singkat IPA adalah pengetahuan yang rasional dan objektif tentang alam semesta dengan segala isinya (Astawan and Agustiana 2020)). IPA merupakan salah satu mata pelajaran pokok dalam kurikulum pendidikan di Indonesia, termasuk pada jenjang sekolah dasar (Dahry and Putra 2020)). IPA sebagai science the board field of human knowledge, acquired by systematic observation and experiment, and explained by means of rules, law, principles, theories, and hypotheses. Artinya IPA adalah pengetahuan manusia yang luas yang didapatkan dengan cara observasi dan eksperimen, serta dijelaskan dengan aturan-aturan, hukum-hukum, prinsip-prinsip, teori-teori, dan hipotesis (Sujana 2014). Keterampilan proses IPA adalah keterampilan yang dilakukan oleh para ilmuwan. Keterampilan tersebut menurut (Permata and Mustadi 2019) di antaranya: keterampilan melakukan observasi, keterampilan mengklarifikasi, keterampilan berkomunikasi, keterampilan memprediksi, keterampilan menginferensi, keterampilan merancang dan melakukan eksperimen, keterampilan mengendalikan variabel, dan keterampilan merumuskan hipotesis.

Berdasarkan observasi yang dilakukan pada mahasiswa STKIP Muhammadiyah tahun ajaran 2019/2020 diperoleh informasi bahwa mahasiswa sering mengalami kesulitan ketika memahami konsep serta memecahkan permasalahan yang berkaitan dengan kehidupan sehari-hari. Hal ini disebabkan pembelajaran IPA masih kurang bervariasi dalam penerapannya membuat mahasiswa menjadi kurang bersemangat. Akibatnya konsep-konsep yang diajarkan kurang membekas lama diingatan mahasiswa sehingga kebingungan memecahkan masalah. Keberhasilan proses kegiatan belajar mengajar pada pembelajaran IPA dapat diukur dari keberhasilan mahasiswa yang mengikuti kegiatan pembelajaran tersebut. Keberhasilan itu dapat dilihat dari tingkat pemahaman, penguasaan materi serta kemampuan mahasiswa dalam mengkomunikasikan konsep yang telah mereka pahami. Semakin tinggi pemahaman dan penguasaan materi serta kemampuan komunikasi mahasiswa maka semakin tinggi pula tingkat keberhasilan mahasiswa dalam belajar (Sarwanto 2016). Pada kenyataannya pembelajaran IPA selama ini belum berhasil meningkatkan pemahaman mahasiswa terhadap konsep-konsep dan keterampilan komuniaksi IPA. Komunikasi ilmiah dianggap Ssebagai komponen utama dalam IPA. Keterampilan komunikasi IPA dapat dijadikan sebagai sumber untuk menciptakan, menjaga, dan memperluas pengetahuan (Urwani, Ramli, and Ariyanto 2018).

Permasalahan ini terlihat pada saat peneliti memberikan beberapa soal yang mengandung pemahaman konsep dan keterampilan komunikasi. Dari fakta yang ada hanya sebagian kecil mahasiswa yang bisa mengerjakan soal tersebut secara benar dan kebanyakan mahasiswa lainnya terlihat kesulitan untuk menyelesaikannya dan memilih untuk membuat sebisanya saja. Gambaran tentang kesulitan mahasiswa menyelesaikan soal pemahaman konsep dan keterampilan komunikasi di atas juga di dukung oleh hasil wawancara dengan beberapa dosen IPA STKIP-MB dalam pembelajaran IPA mahasiswa cenderung hanya mendengarkan, memperhatikan, mencatat dan mengerjakan latihan. Saat dosen memberikan latihan, hanya sebahagian mahasiswa yang serius mengerjakan latihan, sedangkan yang lain sibuk dengan aktivitas yang tidak ada kaitannya dengan IPA sehingga sewaktu dosen meminta untuk mengumpulkan latihan mereka sibuk melihat hasil pekerjaan temannya. Hal tersebut disebabkan oleh kurangnya motivasi mahasiswa untuk mempelajari IPA dan aktivitas mahasiswa dalam pembelajaran IPA juga masih rendah, ketersediaan buku sumber yang terbatas, mahasiswa hanya memiliki satu buku sumber yang diperoleh dari perpustakaan itupun ada mahasiswa yang tidak kebagian buku paket tersebut. Sehingga mahasiswa lebih sering diam dan kurang berpartisipasi dalam pembelajaran. Dosen cenderung langsung menjawab dan berperan sebagai pemberi 
jawaban dari permasalahan yang dihadapi mahasiswa dalam proses pembelajaran. Berdasarkan masalah di atas menyebabkan rendahnya hasil belajar mahasiswa. Hal ini ditunjukan dengan banyaknya mahasiswa yang perolehan nilainya masih di bawah nilai minimum,

Untuk mengatasi masalah tersebut seorang dosen diharapkan dapat meningkatkan pemahaman konsep dan keterampilan komunikasi mahasiswa dalam belajar IPA. Salah satu cara untuk dapat meningkatkan hasil belajar dan keterampilan komunikasi mahasiswa dalam belajar adalah dengan menggunakan pembelajaran Blended Learning. Pada saat masa pandemi proses belajar mengajar dilakukan secara online dan tatap muka, ini dilakukan untuk mengurangi terjadinya penularan qif-19. Maka dari itu metode pembelajaran blended learning sangat cocok digunakan pada situasi sekarang. Pembelajaran IPA dalam kegiatan perkuliahan merupakan transfer ilmu pengetahuan kepada mahasiswa agar memiliki kompetensi pengetahuan atau pengalaman secara langsung yang bersumber dari lingkungan. Selain itu proses pembelajaran IPA juga menekankan kompetensi keterampilan dan sikap ilmiah. Kompetensi pengetahuan sangat berkaitan erat dengan pemahaman konsep (Widiadnyana, Sadia, and Suastra 2014). Jika mahasiswa memiliki pemahaman konsep yang salah, maka pengetahuannya mengalami kesalahan konsep sehingga akan berpengaruh pada keterampilan komunikasi mahasiswa (Oktaviani and Nugroho 2015).

Pemahaman konsep dan keterampilan komunikasi IPA mahasiswa dapat dilakukan dengan metode Blended Learning (BL). Blended learning mengkombinasikan antara sesuatu yang sederhana dan kompleks. Hal yang sederhana dari blended learning adalah mengintegrasikan pembelajaran dengan tatap muka dengan pembelajaran melalui daring (Fitri, Ifdil, and Neviyarni 2016). Terdapat daya tarik intuitif yang cukup besar pada sebuah konsep yang mengintegrasikan kekuatan aktivitas pembelajaran sinkron (tatap muka) dan asinkron (Internet berbasis teks). Pada bagian ini perlu dijelaskan uraian tentang spesifikasi khusus terkait dengan skema. kemungkinan penerapan yang tak terbatas pada banyak konteks (Garrison and Kanuka 2004). Secara umum, blended learning diartikan sebagai kombinasi metode pembelajaran, biasanya yaitu dengan tatap muka dalam kelas dan atau sinkronisasi dengan teknologi (So and Brush 2008).

Metode blended learning (Horn and Staker 2011) "blended learning is any time a student learns, at last in part, at a supervised brick-and-mortar location away from home and at least in part, throught online delivery with some element of student control over time, place, path, and pace". (Watson et al. 2013) blended learning as a formal education program with a student learns at least in put throught online learning, with some element of student control over time, place, path, and pace : at least in part in a supervised brick-andmortal location away from home: and the modalities along each student's learning path with a course or subject are connected to privade an integrated learning experience. Dari pernyataan para ahli tesebut blended learning sebagai program pendidikan formal, dimana seorang mahasiswa pada sebagaian waktu mengikuti kegiatan belajar tatap muka dan sebagian waktu lagi belaajr secara online. Sintak dari metode blended learning ini materi pembelajaran lebih mudah untuk diperbaharui dosen. Kegiatan pembelajaran memungkinkan bisa dirancang secara terpersonalisasi. Pengawasan mahasiswa pun dari jadi lebih mudah. Biaya operasional mahasiswapun lebih terjangkau.

Berdasarkan latar belakang yang dikemukakan di atas, maka dilakukan penelitian yang bertujuan untuk melihat sejauh mana pembelajaran blended learning dapat berpengaruh terhadap pemahaman konsep dan keterampilan komunikasi sains. Untuk itu penelitian ini difokuskan untuk melihat pengaruh blended learning terhadap pemahaman konsep dan keterampilan komunikasi IPA mahasiswa STKIP-MB.

\section{METODE}

Berdasarkan permasalahan dan tujuan yang ingin dicapai, maka penelitian ini menggunakan pendekatan kuantitatif dalam bentuk pretest-posttest nonequivalent group design. Sesuai dengan desain penelitian maka 
4002 Pengaruh Blended Learning terhadap Pamahaman Konsep dan Keterampilan Komunikasi dalam Pembelajaran IPA Mahasiswa PGSD di STKIP Muhammadiyah Muara Bungo - Sundahry, Nurlev Avana

DOI: https://doi.org/10.31004/basicedu.v5i5.1464

penelitian menggunakan dua kelas yaitu kelas eksperimen dan kelas kontrol. Kelas eksperimen adalah kelas yang sengaja diberi perlakuan metode blended learning sedangkan kelas kontrol menggunakan pembelajarn konvensional metode diskusi. Penelitian ini dilaksankan di STKIP-MB. Penelitian ini dilakukan pada semester genap 2020/2021.

Tabel 1. Rancangan Faktorial 2x2

\begin{tabular}{|c|c|c|}
\hline $\begin{array}{l}\text { Metode pembelajaran } \\
\text { Pemahaman konsep }\end{array}$ & $\begin{array}{c}\text { Blended learning } \\
\left(\mathbf{A}_{1}\right)\end{array}$ & $\begin{array}{c}\text { Konvensional } \\
\left(\mathbf{A}_{2}\right)\end{array}$ \\
\hline Tinggi $\left(\mathrm{B}_{1}\right)$ & $\mathrm{A}_{1} \mathrm{~B}_{1}$ & $\mathrm{~A}_{2} \mathrm{~B}_{1}$ \\
\hline Rendah $\left(\mathrm{B}_{2}\right)$ & $\mathrm{A}_{1} \mathrm{~B}_{2}$ & $\mathrm{~A}_{2} \mathrm{~B}_{2}$ \\
\hline Total & \# A1 & X A2 \\
\hline
\end{tabular}

Populasi pada penelitian ini adalah dua kelas mahasiswa STKIP-MB yang terdaftar pada semester genap 2020/2021 yang terdiri dari kelas A dan B. Peneliti mengambil sampel dengan menggunakan teknik porpusive sampling. Teknik ini digunakan karena mempunyai anggota atau unsur yang normal, homogen, dan dari hasil nilai UTS hampir memiliki kemampuan yang sama dengan rata-rata selisihnya 0,2 antara kelas A dan kelas B. Sampel adalah sebagian dari populasi yang memiliki sifat dan karakter yang sama sehingga betul-betul mewakili populasinya (Yusuf 2016). Sampel pada penilitian ini kelas A dan kelas B di STKIPMB. Pelaksanaan penelitian ini diperlukan pola perlakuan (Treatment), dalam hal ini peneliti menyajikan dalam bentuk matrik pola perlakuan antara metode blended learning dengan metode konvensional. Teknik pengumpulan data dalam penelitian ini adalah pretest dan postest. Instrumen digunakan dalam penelitian ini adalah tes yang dilakukan setelah pokok bahasan selesai. Pengembangan instrumen membuat kisi-kisi soal tes, menyusun soal tes sesuai dengan kisi-kisi tes, dan uji coba tes. Setelah data terkumpul, selanjutnya yang akan dilakukan adalah menganalisis data penelitian tersebut melalui teknik analisis data penelitian yang dikelompokkan menjadi dua yaitu: data tes pemahaman konsep dan data tes keterampilan komunikasi memakai N-Gain dan uji hipotesis.

\section{a.Uji Kesahihan (Validitas)}

Validitas taraf sejauh mana alat tes dapat diukur, dan makin tinggi validitas alat tes, maka makin mengena sasarannya (Suryabrata 2000). Valid atau tidaknya suatu item intsrumen, dapat diketahui dengan cara untuk soal objektif :

$$
r p b i=\frac{M p-M t}{S D t} \sqrt{\frac{p}{q}} \quad \text { (Arikunto 2014) }
$$

\section{b. Uji Keterhandalan (Reliabilitas)}

Uji reliabilitas dilakukan untuk mendapatkan tingkat ketepatan alat pengumpul data yang digunakan. Uji reliabilitas dilakukan pada soal-soal yang dikategorikan dipakai atau direvisi. Untuk menentukan reliabilitas tes dipakai rumus Kuder Richardson (KR20) yang dikemukakan oleh (Sugiyono 2013) cari terlebih dahulu standar deviasi soal dengan rumus:

$$
S^{2}=\frac{\sum X^{2}-\sum\left(\frac{X}{N}\right)^{2}}{N}
$$

Untuk mencari $r i=\left(\frac{N}{N-1}\right)\left(\frac{S^{2}-p q}{S^{2}}\right)$ 
4003 Pengaruh Blended Learning terhadap Pamahaman Konsep dan Keterampilan Komunikasi dalam Pembelajaran IPA Mahasiswa PGSD di STKIP Muhammadiyah Muara Bungo - Sundahry, Nurlev Avana

DOI: https://doi.org/10.31004/basicedu.v5i5.1464

\section{c. Daya Pembeda}

Daya pembeda soal adalah kemampuan suatu soal untuk membedakan antara peserta didik yang berkemampuan tinggi dengan peserta didik yang berkemampuan rendah. Untuk mengetahui daya pembeda soal, digunakan rumus yang dikemukakan (Arikunto 2014)berikut :

$$
D P=\frac{B A}{J A}-\frac{B B}{J B}=P A-P B
$$

\section{d. Indeks Kesukaran Tes}

Tingkat kesukaran soal adalah untuk menentukan soal tersebut termasuk soal yang mudah, sedang atau sukar. Tingkat kesukaran soal dapat dihitung dengan menggunakan rumus yang dikemukakan oleh (Arikunto 2014) sebagai berikut:

$$
T K=\frac{\text { Mean }}{\text { Skor maksimum yang telah ditetapkan }}
$$

Dengan mean pada Depdiknas (2001:26) adalah :

$$
\text { Mean }=\frac{\text { jumlah skor pada suatu soal }}{\text { jumlah siswa yang mengikuti tes }}
$$

\section{e. Gain Ternormalisasi (N-Gain)}

Cara menghitung skor Gain yang dinormalisasikan rumus menurut (Jack 2017)

$$
\text { N_Gain }=\frac{\text { Posttest score } \quad-\text { Pretest score }}{\text { Maximum score }- \text { Pretest score }}
$$

Kriteria peningkatan Gain yang dinormalitaskan (Meltzer 2005) sebagai berikut :

$$
\mathrm{G}<0,3 \text { : Peningkatan Rendah }
$$

\begin{tabular}{|c|c|c|c|}
\hline No soal & rpbi & Kriteria penilaian & Keterangan \\
\hline 1 & 0,59 & $0.40-0.60$ (cukup) & Signifikan \\
\hline 2 & 0,026 & $0.00-0.20$ (sangat rendah) & Tidak signifikan \\
\hline 3 & $-0,087$ & $0.00-0.20$ (sangat rendah) & Tidak signifikan \\
\hline 4 & 0,69 & $0.60-0.80$ (tinggi) & Signifikan \\
\hline 5 & 0,087 & $0.00-0.20$ (sangat rendah $)$ & Tidak signifikan \\
\hline 6 & $-0,70$ & $0.00-0.20$ (sangat rendah) & Tidak signifikan \\
\hline 7 & 0,40 & $0.40-0.60$ (cukup) & Signifikan \\
\hline 8 & 0,18 & $0.00-0.20$ (sangat rendah) & Tidak signifikan \\
\hline 9 & 0,46 & $0.40-0.60$ (cukup) & Signifikan \\
\hline 10 & 0,31 & $0.20-0.40$ (rendah) & Tidak signifikan \\
\hline 11 & 0,52 & $0.40-0.60$ (cukup) & Signifikan \\
\hline 12 & 0,64 & $0.60-0.80$ (tinggi) & Signifikan \\
\hline 13 & 0,18 & $0.00-0.20$ (sangat rendah) & Tidak signifikan \\
\hline 14 & 0,52 & $0.40-0.60$ (cukup) & Signifikan \\
\hline
\end{tabular}

$0,3 \leq \mathrm{G} \leq 0,7 \quad$ : Peningkatan Sedang

$\mathrm{G}>0,7$ : Peningkatan Tinggi

\section{HASIL DAN PEMBAHASAN}

Tabel 2. Hasil Perhitungan Validitas Uji Coba Tes Pemahaman Konsep 
4004 Pengaruh Blended Learning terhadap Pamahaman Konsep dan Keterampilan Komunikasi dalam Pembelajaran IPA Mahasiswa PGSD di STKIP Muhammadiyah Muara Bungo - Sundahry, Nurlev Avana

DOI: https://doi.org/10.31004/basicedu.v5i5.1464

\begin{tabular}{llll}
\hline 15 & 0,56 & $0.40-0.60$ (cukup) & Signifikan \\
\hline 16 & 0,50 & $0.40-0.60$ (cukup) & Signifikan \\
\hline 17 & 0,43 & $0.40-0.60$ (cukup) & Signifikan \\
\hline 18 & 0,67 & $0.60-0.80$ (tinggi) & Signifikan \\
\hline 19 & $-0,86$ & $0.00-0.20$ (sangat rendah) & Tidak signifikan \\
\hline 20 & 0,40 & $0.40-0.60$ (cukup) & Signifikan \\
\hline 21 & $-0,30$ & $0.20-0.40$ (rendah) & Tidak signifikan \\
\hline 22 & 0,35 & $0.20-0.40($ rendah $)$ & Tidak signifikan \\
\hline 23 & 0,38 & $0.20-0.40$ (rendah) & Tidak signifikan \\
\hline
\end{tabular}

Berdasarkan tabel 2 terlihat bahwa dari 23 soal yang uji coba yang berikan, soal yang valid berjumlah 12 soal, sehingga yang diberikan pada kelas sampel hanya 10 soal karena sudah mewakili masing-masing dari indikator pembelajaran.

\section{Reliabilitas}

Standar deviasi :

$$
S^{2}=\frac{\sum X^{2}-\sum\left(\frac{X}{N}\right)^{2}}{N} S^{2}=\frac{5371-5162,22}{22} S^{2}=9,49
$$

Mencari Reliabilitas

$$
\mathrm{ri}=\left(\frac{N}{N-1}\right)\left(\frac{S^{2}-p q}{S^{2}}\right) r i=\left(\frac{22}{22-1}\right)\left(\frac{9,49-4,26}{9,49}\right) r i=0,57
$$

Data data di atas diperoleh reliabilitas soal 0,57 itu menandakan soal tersebut cukup $0,40<r_{11} \leq 0,60$ reliabilitas sedang

Tabel 3. Hasil Perhitungan Daya Pembeda Uji Coba Tes Pemahaman Konsep

\begin{tabular}{ccccc}
\hline No soal & PA & PB & Daya Pembeda & Kriteria \\
\hline 1 & 1 & 0,64 & 0,36 & Sedang \\
\hline 2 & 1 & 0,91 & 0,01 & Lemah \\
\hline 3 & 0,73 & 0,64 & 0,09 & Lemah \\
\hline 4 & 0,82 & 0,55 & 0,27 & Cukup \\
\hline 5 & 1 & 0,82 & 0,18 & Lemah \\
\hline 6 & 0,27 & 0,36 & -0.09 & Sedang \\
\hline 7 & 0,91 & 0,55 & 0,36 & Cukup \\
\hline 8 & 0,18 & 0,27 & $-0,09$ & Sedang \\
\hline 9 & 0,82 & 0,55 & 0,27 & Tinggi \\
\hline 10 & 0,55 & 0,18 & 0,37 & Tinggi \\
\hline 11 & 0,91 & 0,36 & 0,55 & Lemah \\
\hline 12 & 0,91 & 0,27 & 0,66 & Sedang \\
\hline 13 & 1 & 0,82 & 0,18 & Lemah \\
\hline 14 & 0,82 & 0,45 & 0,37 & Tinggi \\
\hline 15 & 1 & 0,82 & 0,18 & Sedang \\
\hline 16 & 0,82 & 0,36 & 0,46 & Lemah \\
\hline 17 & 0,82 & 0,45 & 0,37 & Cukup \\
\hline 18 & 0,91 & 0,73 & 0,18 & Lemah \\
\hline 19 & 0,82 & 0,55 & 0,27 & Cukup \\
\hline
\end{tabular}



Pembelajaran IPA Mahasiswa PGSD di STKIP Muhammadiyah Muara Bungo - Sundahry, Nurlev Avana

DOI: https://doi.org/10.31004/basicedu.v5i5.1464

\begin{tabular}{ccccc}
\hline 20 & 0,82 & 0,73 & 0,09 & Cukup \\
\hline 21 & 0,91 & 0,64 & 0,27 & Lemah \\
\hline 22 & 0,36 & 0,18 & 0,18 & Lemah \\
\hline 23 & 0,73 & 0,73 & 1 & Tinggi \\
\hline
\end{tabular}

Berdasrakan tabel 3 dapat dilihat kriteria pada setiap butir soal memiliki perbedaan. Pada soal 9,10, 14, dan 23 dengan kriteria tinggi, pada soal 1,6,8,12,15, dengan kriteria sedang, pada soal 4,7,17,19,20 kriteria cukup, pada soal 2,3,5,11,13,16,18,21,22, kriteria lemah.

Tabel 4. Hasil Perhitungan Indek Kesukaran Uji Coba Tes Pemahaman Konsep

\begin{tabular}{ccc}
\hline No soal & Indek Kesukaran & Kriteria \\
\hline 1 & 0,81 & Mudah \\
\hline 2 & 0,95 & Mudah \\
\hline 3 & 0,68 & Sedang \\
\hline 4 & 0,68 & Sedang \\
\hline 5 & 0,86 & Mudah \\
\hline 6 & 0,31 & Sedang \\
\hline 7 & 0,72 & Mudah \\
\hline 8 & 0,22 & Sukar \\
\hline 9 & 0,68 & Sedang \\
\hline 10 & 0,40 & Sedang \\
\hline 11 & 0,63 & Sedang \\
\hline 12 & 0,59 & Sedang \\
\hline 13 & 0,90 & Mudah \\
\hline 14 & 0,63 & Sedang \\
\hline 15 & 0,90 & Mudah \\
\hline 16 & 0,54 & Sedang \\
\hline 17 & 0,59 & Sedang \\
\hline 18 & 0,81 & Mudah \\
\hline 19 & 0,68 & Mudah \\
\hline 20 & 0,77 & Mudah \\
\hline 21 & 0,77 & Mudah \\
\hline 22 & 0,31 & Sukar \\
\hline 23 & 0,72 & Mudah \\
\hline
\end{tabular}

Berdasrakan tabel 4 dapat dilihat kriteria pada setiap butir soal memiliki perbedaan. Pada soal $1,2,5,7,13,15,18,19,20,21$, dan 23 kriteria tinggi, pada soal pada soal 3,4,6,910,11,12,14,16, dan 17 dengan kriteria sedang, dan pada soal 22 dan 8 kriteria sukar.

Keterampilan komunikasi menggunakan rumus sebagai berikut :

$$
r=\frac{N \sum X Y-\left(\sum X\right)\left(\sum Y\right)}{\sqrt{\left\{N \sum X^{2}-\left(\sum X\right)^{2}\right\} \sqrt{\left\{N \sum Y^{2}-\left(\sum Y\right)^{2}\right\}}}}
$$

Keterangan :

$\mathrm{R} \quad=$ koefesien korelasi pearson 
4006 Pengaruh Blended Learning terhadap Pamahaman Konsep dan Keterampilan Komunikasi dalam Pembelajaran IPA Mahasiswa PGSD di STKIP Muhammadiyah Muara Bungo - Sundahry, Nurlev Avana

DOI: https://doi.org/10.31004/basicedu.v5i5.1464

$$
\begin{aligned}
\sum X Y & =\text { jumlah hasil kali skor } \mathrm{X} \text { dan } \mathrm{Y} \\
\sum X & =\text { jumlah skor } \mathrm{X} \\
\sum Y & =\text { jumlah skor } \mathrm{Y} \\
\sum X^{2} & =\text { jumlah kuadrat skor } \mathrm{X} \\
\sum Y^{2} & =\text { jumlah kuadrat skor } \mathrm{Y} \\
\mathrm{N} & =\text { jumlah peserta }
\end{aligned}
$$

Tabel 5. Hasil Perhitungan Validitas Uji Cob Ates Keterampilan Komunikasi

\begin{tabular}{clll}
\hline No soal & rhitung & Kriteria penilaian & Keterangan \\
\hline 1 & 0,43 & $0.40-0.60$ (cukup) & Signifikan \\
\hline 2 & 0,66 & $0.60-0.80$ (tinggi) & Signifikan \\
\hline 3 & 0,43 & $0.40-0.60$ (cukup) & Signifikan \\
\hline 4 & 0,90 & $0.80-1.00$ (Sangat tinggi) & Signifikan \\
\hline 5 & 0,62 & $0.60-0.80$ (tinggi) & signifikan \\
\hline 6 & 1,39 & - & Tidak signifikan \\
\hline 7 & 1,58 & - & Tidak signifikan \\
\hline 8 & $-1,17$ & $0.00-0.20$ (sangat rendah) & Tidak signifikan \\
\hline 9 & 0,85 & $0.80-1.00$ (Sangat tinggi) & Signifikan \\
\hline 10 & 0,79 & $0.60-0.80$ (tinggi) & Signifikan \\
\hline 11 & 0,58 & $0.40-0.60$ (cukup) & Signifikan \\
\hline 12 & 0,82 & $0.80-1.00$ (Sangat tinggi) & Signifikan \\
\hline
\end{tabular}

Berdasarkan tabel 5 terlihat bahwa dari 12 soal yang uji coba yang berikan, soal yang valid berjumlah 9 soal, sehingga yang diberikan pada kelas sampel hanya 6 soal karena sudah mewakili masing-masing dari indikator pembelajaran.

Kriteria penilaian:

$$
\begin{array}{ll}
0.80-1.00 & \text { : Sangat tinggi } \\
0.60-0.80 & : \text { Tinggi } \\
0.40-0.60 & : \text { Cukup } \\
0.20-0.40 & : \text { Rendah } \\
0.00-0.20 & : \text { Sangat rendah }
\end{array}
$$

\section{Reliabilitas}

$$
\begin{gathered}
r_{11}=\left(\frac{N}{N-1}\right)\left(1-\frac{\sum \sigma_{i}^{2}}{\sigma_{t}^{2}}\right) \quad r_{11}=\left(\frac{22}{22-1}\right)\left(1-\frac{12,81}{42,58}\right) \quad r_{11}=0,29 \\
0,20<\mathrm{r}_{11} \leq 0,40 \quad \text { reliabilitas cukup }
\end{gathered}
$$

Tabel 6. Hasil Perhitungan Daya Pembeda Uji Coba Tes Keterampilan Komunikasi

\begin{tabular}{ccccc}
\hline No soal & PA & PB & Daya Pembeda & Kriteria \\
\hline 1 & 1 & 0,64 & 0,28 & Cukup \\
\hline 2 & 1 & 0,91 & 0,20 & Cukup \\
\hline 3 & 0,73 & 0,64 & 0,18 & Cukup \\
\hline 4 & 0,82 & 0,55 & 0,20 & Cukup \\
\hline 5 & 1 & 0,82 & 0,23 & Cukup \\
\hline
\end{tabular}


4007 Pengaruh Blended Learning terhadap Pamahaman Konsep dan Keterampilan Komunikasi dalam Pembelajaran IPA Mahasiswa PGSD di STKIP Muhammadiyah Muara Bungo - Sundahry, Nurlev Avana

DOI: https://doi.org/10.31004/basicedu.v5i5.1464

\begin{tabular}{ccccc}
\hline 6 & 0,27 & 0,36 & 0,23 & Cukup \\
\hline 7 & 0,91 & 0,55 & 0,18 & Lemah \\
\hline 8 & 0,18 & 0,27 & 0,30 & Cukup \\
\hline 9 & 0,82 & 0,55 & 0,20 & Cukup \\
\hline 10 & 0,55 & 0,18 & 0,18 & Lemah \\
\hline 11 & 0,91 & 0,36 & 0,28 & Cukup \\
\hline 12 & 0,91 & 0,27 & 0,18 & Lemah \\
\hline
\end{tabular}

Berdasarkan tabel 6 dapat dilihat kriteria pada setiap butir soal memiliki perbedaan. Pada soal 1,2,3,4,5,6,8,9, dan 11 dengan kriteria cukup, dan pada soal 7,10, dan 11 dengan kriteria lemah.

Tabel 7. Hasil Perhitungan Indek Kesukaran Uji Coba Tes Keterampilan Komunikasi

\begin{tabular}{cll}
\hline No soal & Indek Kesukaran & Kriteria \\
\hline 1 & 0,81 & Mudah \\
\hline 2 & 0,95 & Mudah \\
\hline 3 & 0,68 & Sedang \\
\hline 4 & 0,68 & Sedang \\
\hline 5 & 0,86 & Mudah \\
\hline 6 & 0,27 & Sukar \\
\hline 7 & 0,22 & Sukar \\
\hline 8 & 0,22 & Sukar \\
\hline 9 & 0,68 & Sedang \\
\hline 10 & 0,40 & Sedang \\
\hline 11 & 0,63 & Sedang \\
\hline 12 & 0,59 & Sedang \\
\hline
\end{tabular}

Berdasarkan tabel 7 dapat dilihat kriteria pada setiap butir soal memiliki perbedaan. Pada soal 1 dan 2 kriteria mudah, pada soal pada soal 3,4,9,10,11, dan 12 dengan kriteria sedang, dan pada soal 6,7 , dan 8 kriteria sukar.

Pada bagian ini akan dipaparkan data untuk mengungkapkan hasil keterampilan komunikasi dan pemahaman konsep mahasiswa pada kelas eksperimen dan kontrol. Data tes keterampilan komunikasi memakai N-Gain, dan uji hipotesis. Berdasarkan perolehan nilai rata-rata pretest terlihat nilai keterampilan komunikasi pada kelas eksperimen sebesar 77,2 dari nilai ideal 95 dan kelas kontrol sebesar 74,2 dari hasil ideal 90. Nilai tes awal kelas kontrol lebih rendah dibandingkan dengan kelas eksperimen. Nilai rata-rata tes akhir (posttest) Keterampilan komunikasi pada kelas eksperimen sebesar 82,60 dan kelas kontrol 78,50. Hal ini menunjukan nilai posttest eksperimen lebih tinggi dibandingkan kelas kontrol. Selanjutnya untuk perolehan rata-rata $\mathrm{N}-$ Gain kelas eksperimen dan kontrol dapat dilihat pada tabel 8.

Tabel 8. Perbedaan N-Gain Nilai Rata-rata Keterampilan Komunikasi di Kelas Eksperimen dan Kontrol Secara Keseluruhan

\begin{tabular}{llllll}
\hline $\begin{array}{l}\text { Kelompok } \\
\text { Siswa }\end{array}$ & $\begin{array}{l}\text { Rata-rata Pretes } \\
\left(\bar{x}_{1}\right)\end{array}$ & $\begin{array}{l}\text { Rata-rata } \\
\text { Posttes }\left(\bar{x}_{2}\right)\end{array}$ & $\begin{array}{l}\text { Selisih skor }\left(\bar{x}_{2}\right. \\
\left.-\bar{x}_{\mathbf{1}}\right)\end{array}$ & N_Gain & Ket \\
\hline Eksperimen & 77,20 & 81,60 & 4,4 & 0,45 & Sedang \\
\hline Kontrol & 74,20 & 78,50 & 4,3 & 0,13 & Rendah \\
\hline
\end{tabular}


Data tersebut menunujukan N-Gain kelas eksperimen lebih tinggi dari kelas kontrol. Hal ini terjadi karena metode blanded learning mampu membuat mahasiswa untuk fokus selama pembelajaran dan membuat mahasiswa lebih aktif dalam proses pembelajaran.

\section{Hipotesis Pertama}

Hipotesis pertama menyatakan bahwa "keterampilan komunikasi mahasiswa yang menggunakan metode blended learning lebih tinggi dari pada keterampilan komunikasi mahasiswa yang mengggunakan pembelajaran konvensional". Berdasarkan hasil perhitungan uji-t, diperoleh hasil analisis dari kedua kelas eksperimen dan kontrol pada tabel 9 berikut :

Tabel 9. Hasil Uji Hipotesis Pertama

\begin{tabular}{lllllll}
\hline KK & Kelas & $\mathbf{n}$ & $\bar{x}$ & $\mathbf{T}_{\text {hitung }}$ & $\mathbf{T}_{\text {tabel }}$ & ket \\
\hline Pretest & Eksperimen & 30 & 77,2 & 0,86 & 1,708 & $\mathrm{t}_{\text {hitung }}<\mathrm{t}_{\text {tabel }}$ \\
\cline { 1 - 3 } \cline { 1 - 3 } & Kontrol & 30 & 74,2 & & & $\mathrm{H}_{\mathrm{o}}$ diterima \\
\hline Posttest & Eksperimen & 30 & 82,6 & \multirow{2}{*}{1,91} & 1,708 & $\mathrm{t}_{\text {hitung }}>\mathrm{t}_{\text {tabel }}$ \\
\cline { 1 - 3 } \cline { 1 - 3 } & Kontrol & 30 & 78,5 & & & $\mathrm{H}_{\mathrm{o}}$ ditolak \\
\hline
\end{tabular}

Hasil perhitungan pada tabel 24 dengan menggunakan uji t diperoleh bahwa pada tes awal (pretest) $\mathrm{t}$ hitung $=0,86$ pada taraf $\mathrm{a}=0,05$ diperoleh $\mathrm{t}_{\text {tabel }}=1,708$ karena $\mathrm{t}_{\text {hitung }}<\mathrm{t}_{\text {tabel }}$ sehingga $\mathrm{H}_{\mathrm{o}}$ diterima artinya tidak ada terdapat perbedaan yang signifikan antara kelas kontrol dan kelas eksperimen pada rata-rata nilai tes awal keterampilan komunikasi. Kemudian pada posttest terlihat adanya perbedaan yang signifikan antara kelas kontrol dan kelas eksperimen $t_{\text {hitung }}=1,91$ pada taraf $\mathrm{a}=0,05$ diperoleh $\mathrm{t}_{\text {tabel }}=1,708$ karena $\mathrm{t}_{\text {hitung }}>\mathrm{t}_{\text {tabel }}$ artinya $\mathrm{H}_{\mathrm{o}}$ ditolak dan $\mathrm{H}_{1}$ diterima yaitu keterampilan komunikasi mahasiswa yang diajar dengan metode blended learning secara signifikan lebih tinggi.

\section{Hipotesis Kedua}

Hipotesis yang kedua menyatakan bahwa "keterampilan komunikasi mahasiswa yang memiliki pemahaman konsep tinggi yang menggunakan metode blended learning lebih tinggi dari keterampilan komunikasi mahasiswa yang menggunakan pembelajaran konvensional". Berdasarkan hasil perhitungan uji-t diperoleh analisis dari kedua kelas eksperimen dan kontrol sebagai berikut pada tabel 10 berikut :

Tabel 10. Hasil Uji Hipotesis Kedua

\begin{tabular}{lllllll}
\hline KK & Kelas & $\mathbf{n}$ & $\bar{x}$ & $\mathbf{t}_{\text {hitung }}$ & $\mathbf{t}_{\text {tabel }}$ & ket \\
\hline Posttest & Eksperimen & 18 & 89,72 & 1,87 & 2,56 & $\mathrm{t}_{\text {hitung }}<\mathrm{t}_{\text {tabel }}$ \\
\cline { 1 - 3 } & Kontrol & 12 & 87,50 & & & $\mathrm{H}_{0}$ diterima \\
\hline
\end{tabular}

Hasil perhitungan pada tabel diatas diperoleh pada tes akhir $\mathrm{t}_{\text {hitung }}=1,87$ pada taraf $\mathrm{a}=0,05$ diperoleh $\mathrm{t}$ tabel $=2,56$ karena $\mathrm{t}_{\text {hitung }}<\mathrm{t}_{\text {tabel }}$ sehingga $\mathrm{H}_{0}$ diterima artinya tidak terdapat perbedaan yang signifikan antara keterampilan komunikasi mahasiswa yang memiliki pemahaman konsep tinggi yang menggunakan metode blended learning dan keterampilan komunikasi mahasiswa dengan pemahaman konsep tinggi di kelas kontrol.

\section{Hipotesis Ketiga}

Hipotesis yang kedua menyatakan bahwa "keterampilan komunikasi mahasiswa yang memiliki pemahaman konsep rendah yang menggunakan metode blended learning lebih tinggi dari keterampilan komunikasi mahasiswa yang menggunakan pembelajaran konvensional". Berdasarkan hasil perhitungan uji-t diperoleh analisis dari kedua kelas eksperimen dan kontrol sebagai berikut pada tabel 11 berikut : 

Pembelajaran IPA Mahasiswa PGSD di STKIP Muhammadiyah Muara Bungo - Sundahry, Nurlev Avana

DOI: https://doi.org/10.31004/basicedu.v5i5.1464

Tabel 11. Hasil Uji Hipotesis Ketiga

\begin{tabular}{|c|c|c|c|c|c|c|}
\hline KK & Kelas & $\mathbf{N}$ & $\bar{x}$ & $t_{\text {hitung }}$ & $\mathbf{t}_{\text {tabel }}$ & ket \\
\hline Posttest & Eksperimen & 7 & 72,85 & \multirow[t]{2}{*}{3,71} & \multirow[t]{2}{*}{2,56} & $\mathrm{t}_{\text {hitung }}>\mathrm{t}_{\text {tabel }}$ \\
\hline & Kontrol & 13 & 57,69 & & & $\mathrm{H}_{0}$ ditolak \\
\hline
\end{tabular}

Hasil perhitungan pada tabel diatas diperoleh pada tes akhir $\mathrm{t}_{\text {hitung }}=3,71$ pada taraf $\mathrm{a}=0,05$ diperoleh $\mathrm{t}$ tabel $=2,56$ karena $\mathrm{t}_{\text {hitung }}>\mathrm{t}$ tabel sehingga $\mathrm{H}_{0}$ ditolak artinya terdapat perbedaan yang signifikan antara kelas kontrol dengan kelas eksperimen, nilai rata-rata kelas eksperimen memiliki rata-rata yang tinggi dibandingkan kelas kontrol, artinya $\mathrm{H}_{0}$ ditolak dan $\mathrm{H}_{1}$ diterima yaitu keterampilan komunikasi mahasiswa yang memiliki pemahaman konsep rendah yang diajar menggunakan metode blended learning lebih tinggi dari pada keterampilan komunikasi mahasiswa dengan pemahaman konsep rendah di kelas kontrol.

\section{Hipotesis Keempat}

Hipotesis yang keempat menyatakan bahwa "adanya interaksi metode blended learning dan pemahaman konsep terhadap keterampilan komunikasi ". Pada hipotesis ini dilakukan dengan teknik ANOVA dua jalur atau berulang (Sarwano, 2012:56). Penggunaan teknik ANOVA dua jalur bertujuan untuk mengetahui kontribusi individual dari variabel bebas terhadap hasil eksperimen (main effect) dan untuk mengetahui pengaruh interaksi (interaction effect). Hasil perhitungan analisis data disajikan pada tabel berikut.

Tabel 12. Rangkuman Hasil ANOVA Dua Jalur terhadap Data Keterampilan komunikasi dalam pembelajaran IPA

\begin{tabular}{lllllll}
\hline Sumber Varian & $\mathbf{J K}$ & $\mathbf{d k}$ & $\mathbf{R J K}=\mathbf{J K} / \mathbf{d k}$ & $\begin{array}{l}\mathbf{F h}= \\
\mathbf{R J K} / \mathbf{R J K D}\end{array}$ & $\begin{array}{l}\mathbf{F t} \\
(\mathbf{a = 0 , 0 5})\end{array}$ & Ket \\
\hline $\begin{array}{l}\text { Antar metode } \\
\text { pembelajaran } \\
\text { (a) }\end{array}$ & 33066,93 & 1 & 33066,93 & 4,05 & 4,01 & $\mathrm{H}_{1}$ diterima \\
\hline $\begin{array}{l}\text { Antar } \\
\text { pemahaman }\end{array}$ & 42180,01 & 1 & 42180,01 & 4,67 & 4,01 & $\mathrm{H}_{1}$ diterima \\
$\begin{array}{l}\text { konsep } \\
\text { belajar(b) }\end{array}$ & & & & & & \\
\hline Interaksi (axB) & 5784,45 & 1 & 5784,45 & 0,68 & 4,01 & $\mathrm{H}_{0}$ diterima \\
\hline Galat & 417547,55 & 42 & 987 & & & \\
\hline Total & 124151,98 & 46 & & & & \\
\hline
\end{tabular}

Pada tabel dapat dilihat bahwa nilai $\mathrm{F}_{\text {hitung }}=-1,04<\mathrm{F}_{\text {tabel }}=4,012$. Hal ini berarti $\mathrm{H}_{\mathrm{o}}$ diterima dan $\mathrm{H}_{1}$ ditolak artinya efek faktor pemahaman konsep tidak mempengaruhi metode pembelajaran terhadap keterampilan komunikasi mahasiswa. Maka dapat ditarik kesimpulan bahwa tidak terdapat interaksi secara signifikan antara metode pembelajaran dan pemahaman konsep terhadap keterampilan komunikasi IPA. Hal ini dideskripsikan pada gambar 1 : 

Pembelajaran IPA Mahasiswa PGSD di STKIP Muhammadiyah Muara Bungo - Sundahry, Nurlev Avana

DOI: https://doi.org/10.31004/basicedu.v5i5.1464

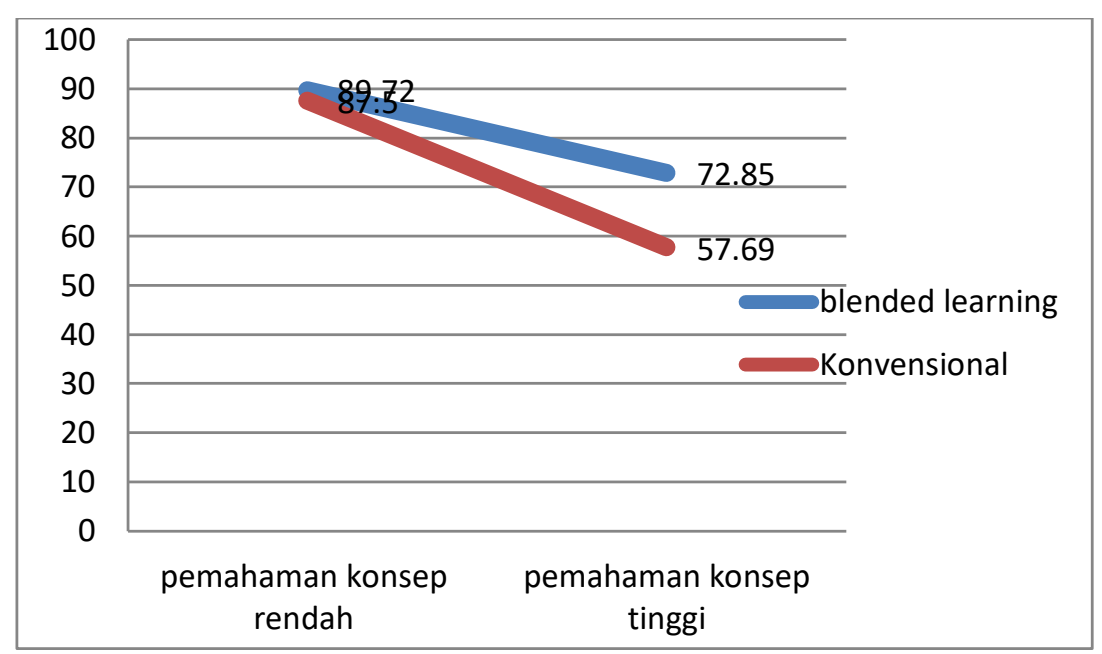

Gambar 1. Tidak Terdapat Interaksi antara Metode Pembelajaran dengan Pemahaman Konsep terhadap Keterampilan komunikasi dalam pembelajaran IPA

Berdasarkan uji hipotesis, ditunjukkan bahwa keterampilan komunikasi mahasiswa yang diajarkan dengan metode blended learning tidak dipengaruhi oleh pemahaman konsep. Hal ini terlihat dari $\mathrm{F}_{\text {hitung }}$ lebih kecil dari $\mathrm{F}_{\text {tabel }}(-1,04<4,02)$. Pada grafik di atas dapat dilihat, jika kedua garis diteruskan ke sisi kiri atas maka akan terjadi perpisahan garis yang menggambarkan tidak adanya interaksi.

\section{KESIMPULAN}

Berdasarkan temuan penelitian dan pembahasan hasil penelitian maka dapat disimpulkan sebagai berikut:

1.Keterampilan komunikasi mahasiswa yang memperoleh pembelajaran metode blended learning lebih tinggi daripada keterampilan komunikasi mahasiswa memperoleh pembelajaran konvensional dalam pembelajaran IPA, sehingga metode blended learning dapat meningkatkan keterampilan komunikasi mahasiswa.

2.Keterampilan komunikasi mahasiswa dengan pemahaman konsep tinggi yang memperoleh pembelajaran metode blended learning lebih tidak ada perbedaan yang signifikan dengan keterampilan komunikasi mahasiswa yang memperoleh pembelajaran konvensional dalam pembelajaran IPA. Hal ini karena mahasiswa yang memiliki pemahaman konsep tinggi sudah mampu menghubungkan tahap-tahap konsep.

3. Keterampilan komunikasi mahasiswa dengan pemahaman konsep rendah yang memperoleh pembelajaran metode blended learning lebih tinggi daripada keterampilan komunikasi mahasiswa yang memperoleh pembelajaran konvensional dalam pembelajaran IPA. Hal ini karena adanya efek pemahaman konsep berpengaruh besar dalam membangun pengetahuan baru dengan bantuan pengelaman sebelumnya.

4.Tidak terdapat interaksi antara metode pembelajaran dengan pemahaman konsep mahasiswa terhadap keterampilan komunikasi.

\section{UCAPAN TERIMA KASIH}

Ucapan terima kasih yang sebesarnya disampaikan kepada Dirjen DIKTI melalui LLDIKTI Wilayah X Padang yang telah memberikan pendanaan anggaran penelitian ini sehingga semua tahapan penelitian dapat berjalan sesuai perencanaan. Begitu juga kepada Ketua STKIP Muhammadiyah Muara Bungo beserta civitas akademik yang telah memberikan sumbangsih berupa saran dan pemikirannya. Tidak terlupakan kepada 
4011 Pengaruh Blended Learning terhadap Pamahaman Konsep dan Keterampilan Komunikasi dalam Pembelajaran IPA Mahasiswa PGSD di STKIP Muhammadiyah Muara Bungo - Sundahry, Nurlev Avana

DOI: https://doi.org/10.31004/basicedu.v5i5.1464

LP3M STKIP Muhammadiyah Muara Bungo yang memberi suport, pelatihan, bimbingan dalam penelitian skema dosen pemula ini.

\section{DAFTAR PUSTAKA}

Arikunto, Suharsimi. 2014. "Dasar-Dasarevaluasi Pendidikan, Jakarta: PT Bumi Aksara." Prosedur Penelitian Suatu Pendekatan Praktik, Jakarta: Renika Cipta.

Astawan, I Gede, And I Gusti Ayu Tri Agustiana. 2020. Pendidikan IPA Sekolah Dasar Di Era Revolusi Industri 4.0. Nilacakra.

Dahry, Sundahry. 2020. "Peningkatan, Hasil Belajar, Mode Peningkatan Hasil Belajar Ipa Siswa Kelas Iv Melalui Model Pengajaran Terbalik." Jurnal Tunas Pendidikan 3 (1): 22-32.

Dahry, Sundahry, And Yogi Irdes Putra. 2020. "Peningkatan Hasil Belajar Kognitif Ipa Siswa Kelas Iv Melalui Model Reciprocal Teaching." Jurnal Muara Pendidikan 5 (2): 712-20.

Fitri, Emria, Ifdil Ifdil, And S Neviyarni. 2016. "Efektivitas Layanan Informasi Dengan Menggunakan Metode Blended Learning Untuk Meningkatkan Motivasi Belajar." Jurnal Psikologi Pendidikan Dan Konseling: Jurnal Kajian Psikologi Pendidikan Dan Bimbingan Konseling 2 (2): 84-92.

Garrison, D Randy, And Heather Kanuka. 2004. "Blended Learning: Uncovering Its Transformative Potential In Higher Education.” The Internet And Higher Education 7 (2): 95-105.

Horn, Michael B, And Heather Staker. 2011. "The Rise Of K-12 Blended Learning.” Innosight Institute 5: 117.

Jack, Gladys Uzezi. 2017. "The Effect Of Learning Cycle Constructivist-Based Approach On Students Academic Achievement And Attitude Towards Chemistry In Secondary Schools In North-Eastern Part Of Nigeria." Educational Research And Reviews 12 (7): 456-66.

Meltzer, David E. 2005. "Relation Between Students' Problem-Solving Performance And Representational Format." American Journal Of Physics 73 (5): 463-78.

Oktaviani, Atiko Nur, And Sunyoto Eko Nugroho. 2015. "Penerapan Model Creative Problem Solving Pada Pembelajaran Kalor Untuk Meningkatkan Pemahaman Konsep Dan Keterampilan Komunikasi.” UPEJ Unnes Physics Education Journal 4 (1).

Permata, Santy Dinar, And Ali Mustadi. 2019. "Peningkatan Keterampilan Komunikasi Saintifik Melalui Group Investigation (GI) Pada Calon Guru Sekolah Dasar." Sekolah Dasar: Kajian Teori Dan Praktik Pendidikan 28 (2): 103-14.

Sarwanto, Sarwanto. 2016. "Peran Komunikasi Ilmiah Dalam Pembelajaran IPA." In Prosiding SNPS (Seminar Nasional Pendidikan Sains), 3:35-40.

So, Hyo-Jeong, And Thomas A Brush. 2008. "Student Perceptions Of Collaborative Learning, Social Presence And Satisfaction In A Blended Learning Environment: Relationships And Critical Factors." Computers \& Education 51 (1): 318-36.

Sugiyono, Prof Dr. 2013. "Metode Penelitian Manajemen." Bandung: Alfabeta, CV.

Sujana, Atep. 2014. Dasar-Dasar IPA: Konsep Dan Aplikasinya. UPI Press.

Suryabrata, Sumadi. 2000. "Pengembangan Alat Ukur Psikologis." Yogyakarta: Penerbit Andi.

Urwani, Assabai Nizar, Murni Ramli, And Joko Ariyanto. 2018. "Analisis Keterampilan Komunikasi Pada Pembelajaran Biologi Sekolah Menengah Atas.” Jurnal Inovasi Pendidikan IPA 4 (2): 181-90.

Watson, John, Amy Murin, Lauren Vashaw, Butch Gemin, And Chris Rapp. 2013. "Keeping Pace With K-12 Online \& Blended Learning: An Annual Review Of Policy And Practice. 10 Year Anniversary Issue." 
4012 Pengaruh Blended Learning terhadap Pamahaman Konsep dan Keterampilan Komunikasi dalam Pembelajaran IPA Mahasiswa PGSD di STKIP Muhammadiyah Muara Bungo - Sundahry, Nurlev Avana

DOI: https://doi.org/10.31004/basicedu.v5i5.1464

Evergreen Education Group.

Widiadnyana, I Wayan, I Wayan Sadia, And I Wayan Suastra. 2014. "Pengaruh Model Discovery Learning Terhadap Pemahaman Konsep IPA Dan Sikap Ilmiah Siswa SMP.” Jurnal Pendidikan Dan Pembelajaran IPA Indonesia 4 (2).

Yusuf, A Muri. 2016. Metode Penelitian Kuantitatif, Kualitatif \& Penelitian Gabungan. Prenada Media. 